\title{
The impact of creative accounting methods on earnings per share
}

\author{
Nancy Al-Natsheh ${ }^{a}$ and Saleh Al-Okdeh ${ }^{a^{*}}$
}

${ }^{a}$ Applied science private university, Jordan

\begin{tabular}{l}
\hline C H R O N I C L E \\
\hline Article history: \\
Received: September 42019 \\
Received in revised format: Sep- \\
tember 4 2019 \\
Accepted: October 12, 2019 \\
Available online: \\
October 12, 2019 \\
\hline Keywords: \\
Creative Accounting \\
Earnings Management \\
Income Smoothing \\
Earnings Per Share
\end{tabular}

\section{Introduction}

The financial statements provide information used by interested parties to evaluate the performance of the managers and to make the economic decisions. Therefore, some companies may misrepresent financial statements before they are issued by using some of the creative methods to create balances that do not indicate the real status of these companies. According to some of the management interests, departments may make financial statements on a consistent basis and according to rules that make them reliable to users. In the first decade of the second millennium, there were many financial scandals including Arthur Andersen and Enron due to the use of innovation in the financial statements, which led to a lack of transparency in the financial statements. The Earnings Management and Income Smoothing represent one of the creative accounting methods which were used to manipulate financial statements that reflect the real situation in the company, through the exploitation of alternatives available in some laws and standards, or because of the multiplicity of accounting policies that allow the company to follow in the areas of measurement and disclosure in the preparation of the financial statements, which will be reflected on manipulated data where their credibility will be affected (Matar, 2016). Although, creative accounting is one of the ways of manipulation and fraud in the accounting profession, it appears legal according to the laws and standards followed. Therefore, it may be difficult to be discovered because of its different ways. The main purpose of using creative accounting methods is to show the company's profit in a way that influences the decisions of users of the financial statements and to show the best image of the company management (Matar, 2016). Financial statements play an important role in helping investors make their future decisions. Earnings per share is one of the indicators that investors are interested about because it shows the profitability of the company. Therefore, earnings management is one of the most important goals of creative accounting, where the real image of income is changed, especially since the recession that occurred after the collapse of some American companies and other international companies (Matar, 2016). Also, one of the goals of creative accounting is to influence share prices, where

\footnotetext{
* Corresponding author
}

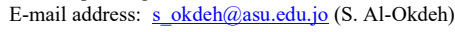

C 2020 by the authors; licensee Growing Science, Canada doi: $10.5267 /$ j.msl.2019.10.014 
the retreat of the company's performance impacts directly or indirectly on the share prices of companies in the Exchange, and the stability of the company's results may lead to the stability of the share prices, which in turn leads companies to the use of creative accounting. Creative accounting is like two sides of the coin, where it contains aspects of innovation and creativity that can be used to achieve goals that serve all interests. At the same time, it is used in ways that do not serve all parties but serve the interests related to the management. Therefore, it is necessary to adjust all the creative accounting practices to face negative creativity and exploit the positive creativity. Some companies are using creative accounting methods to achieve several objectives such as maximizing earnings to increase dividends, attracting new investors or reducing them for tax evasion, and impacting on earnings per share for certain objectives. Also, because of the significant role of accounting in providing financial information to investors and external stakeholders, it is necessary to provide reliable and appropriate information to those parties. Therefore, the current study focuses on two methods of creative accounting which are earnings management and income smoothing in addition to their impacts on earnings per share in the Jordanian industrial public shareholding companies. The study includes four main sections. The first section includes the introduction. The second section presents the previous studies related to the subject of creative accounting practices. The third section contains the study methodology, the tests of statistical analysis and the results. The last section includes the study summary and the recommendations reached.

\subsection{Creative Accounting}

Creative accounting has been defined as: some or all of the steps used to play the financial figures game, which includes arbitrary selection of applying accounting principles, and fraud in the financial report, and any other steps taken for earnings management and income smoothing (Al-Qari, 2010). It has also been defined as: the process of changing the accounting figures from the real form to the desired form to achieve the advantages to the company and its management through the disclosure of this information, by choosing between alternatives of accounting policies or ignoring some of them (Khattab, 2012). There are many factors and reasons that led to the emergence of creative accounting such as the freedom of choice between accounting principles, the freedom of accounting estimates, big competition between companies, trying to evade taxes, and maintaining the share price (Naffaa, 2015), which led to the need to generate earnings that do not exist in reality, through the use of accountants of their experience and knowledge in the accounting rules and laws and flexibility in choosing of accounting principles and standards, and exploiting the existing gaps. Therefore, creative accounting played an important and effective role in preparing the financial statements, either to maintain the share price or to use earnings management methods and income smoothing to make the risk between the financial statement numbers (Hamada, 2010).

\subsection{Earning Management}

Earnings management method is considered as one of the most important creative accounting methods that are used from other methods, where the management uses this method to impact on the financial statements, because it does not completely contradict with accounting principles and standards, through exploiting the gaps exist in the accounting standards. Earnings management is defined as "part of creative accounting, where it is the strategy used to manipulate the company's earnings to match the goals previously defined" (Rahman et al., 2013). As the earnings management is one of the most important methods of creative accounting, it can be used in two ways which are Real Earning Management, which in turn affects the cash flow, or by using accounting benefits, and those are the most important earnings management tools that are used by managements either to increase or to decrease income, or through a change in estimates and accounting policies, which is the most widespread and used form (Bora \& Saha, 2016).

\subsection{Income Smoothing}

The income fluctuations is one of the most important goals for executives since managers believe that income fluctuations increases risk, and that companies with lower earnings fluctuations are considered less risky. Therefore, some companies try to reduce this risk by using acceptable accounting methods that called income smoothing (Shammari, 2016). Income smoothing is defined as: a set of management procedures used by management through exploiting the flexibility available to them in selecting accounting policies and procedures to reduce income fluctuations over successive years, which is an attempt to show income more stable (Acharya \& Lambrecht, 2011).

\section{Literature Review}

Companies' managements use various accounting procedures in order to achieve an unrealistic improvement in their profitability and financial position in order to take advantage of the multiplicity of alternatives available in the accounting policies provided by accounting standards for companies to follow in the measurement and disclosure techniques used in the financial statements, as an attempt by the management to achieve several benefits such as increasing share price (Jabbar, 2015), which led many researchers to investigate creative accounting practices.

The study of Ba'aj (2018) aimed at investigating the impact of using creative accounting methods on the quality of accounting information for companies' financial reports, identifying the methods that allowed the management to manipulate financial statements, and clarifying procedures that reduce the creative accounting practices in Iraqi companies. The study sample consisted of staff working in the control departments, internal audit, and financial department, financial analysts and financial intermediaries). The study found that the creative accounting practices which are changing the methods and accounting estimates impact on the quality of the accounting information, as well as there was an inverse relationship between the quality of 
accounting information and the creative accounting practices represented by biased methods and estimates to a previously defined goal.

Also, the study of Al-Hadi et al. (2017) aimed to examine the extent of practicing of the Jordanian companies of earnings management, to find the impact of earnings management practices on the management of accounting earnings, to know the impact of company size, ratio of indebtedness, and return on assets on the management of accounting earnings announced in the Jordanian industrial companies. The study found that earnings management of Jordanian industrial companies declined in general. Also, the findings revealed the practice of Jordanian industrial companies of earnings management that aim to reduce earnings. The results of the regression analysis showed that there was a negative impact of earnings management practices and methods on earnings management, while there was a positive impact of the ratio of indebtedness on earnings management. Moreover, the study of Al Hadi et al. (2017) aimed to identify creative accounting practices and their impact on trading volume in the Iraqi Stock Exchange, to find the extent of reflection of the companies' management practices listed in the Iraqi Stock Exchange of creative accounting, and to determine the ways that can be used to reduce the spread of the creative accounting phenomenon. The Miller model was used to measure the earnings practices. The study found that the service sector managements practiced creative accounting to show their earnings at a high level which increases the value of their shares.

As for Mostafa (2017), the study aimed to investigate the relationship between earnings management and the importance of earnings value, and whether earnings management practices reduce the importance of earnings value, and examined the relationship between the declared earnings and the earnings per share in Egyptian companies. The study concluded that there was a positive impact of company's use of accounting management practices with lower operational performance more than companies with higher operational performance, and the earnings response factor was much lower for earnings of companies with lower operational performance than those companies with high operational performance. Another study was conducted by Abdulrahman and Hashim (2016) which aimed to identify the impact of earnings management practice on the evaluation of financial performance of listed banks in the Khartoum Stock Exchange. The indicators of financial performance represented by profitability indicators, activity indicators, and share price to its profitability. Modified Jones Model was used to estimate the banks practicing of earnings management. The study concluded the following results: the sample banks practiced earnings management during the study period by $(80 \%)$, this has a positive impact on of the evaluation of their financial performance through its impact on the indicators of profitability, activity and share price to profitability, and earnings management practices impacted on the profitability of the listed banks during the study period. Furthermore, the study of Al-Shammari (2016) aimed to find the impact of income smoothing on the financial performance, and to determine the potential relationship between the income smoothing and the financial performance ratios of the Housing Bank for Trade and Finance in Jordan. The De Angleo model (1986) was used. The study found that there was a statistically significant impact of practicing the income smoothing on the financial performance measured by (return on assets and return on equity), and there was a statistically significant impact of practicing the income smoothing on the financial performance measured by earnings per share especially in periods that the Bank's earnings reduce.

Another study aimed to develop a theoretical framework for creative accounting and its practice in Iraqi companies and its impact on the reliability of data, to find the role of creative accounting in the earnings management, and to determine the impact of creative accounting and earnings management on the market value of shares in Iraqi banks. The study concluded that creative accounting methods could lead to maximize earnings, and impact on the market value of shares, there was positive and moral correlation between creative accounting and maximizing earnings, and there was positive and moral correlation between creative accounting and the market value of shares. Hatef et al. (2015) aimed to find the correlation between earnings management practices and the returns of shares of UAE industrial companies. The Modified Jones Model (1995) was used to calculate the total accruals and non-optional accruals. The study concluded companies practiced earnings management in the years 2006, 2010, and 2011 and there were no practices in other years, as well as the highest year in practicing earnings management was 2006. As for Matar and Halabi (2014), the aim of the study was to determine the extent of practicing of earnings management methods and the implications of this on the reliability of the financial statements in the Jordanian industrial public shareholding companies. A questionnaire was distributed to the study sample. The study concluded that the categories included in the study sample agreed that the methods and procedures used in earnings management had different effects on the financial statements, the most influential are the methods and procedures practiced by the management when conducting fraudulent operations in the field of fraud, and the least influential on the financial statements was practiced in the field of income smoothing. The study of Khoury and Shakhatra (2014) aimed to investigate whether Jordanian service companies practice the policy of income smoothing, and to determine the most important factors which impact on the policy of income smoothing. Income levels were divided into: net operational income, net income before tax, net income, and earnings per share. The study concluded that there was no statistically significant relationship between the company profitability factor and dividends distribution factor with the policy of income smoothing using all levels of income, and there was statistically significant relationship between the indebtedness and tax payments factor with the policy of income smoothing using the net income level.

\section{Methodology and Outcomes}

\subsection{Data}

This study used a quantitative analytical method based on a test study of the real financial statements recorded in the financial statements and annual reports issued by 57 industrial companies listed on the Amman Stock Exchange to find data related to 
creative accounting methods and their impact on earnings per share during the period from 2008 to 2017 , in order to test the study hypothesis and answer its questions to reach the appropriate results.

\subsection{Measures of Variables}

\subsubsection{Earnings Management}

Earnings management was measured by using the modified Jones model (Dechow et al., 1995), or what is known as the optional accruals method, and the optional accruals are calculated by the following steps:

First: Determination of total accruals:

$T A C C_{i, t}=N I_{i, t}-O C F_{i, t}$

where

$T A C C_{i, t}=$ total accruals of company $i$, in year $t$.

$N I_{i, t}=$ net income of company $i$, in year $t$.

$O C F_{i, t}=$ Operating cash flow of company $i$, in year $t$.

Second: Estimation of the slope $\left(\beta_{1}, \beta_{2}, \beta_{3}\right)$ in the following regression model:

$\frac{\text { TACC }_{i, t}}{A_{i, t-1}}=\alpha+\beta_{1}\left(\frac{1}{A_{i, t-1}}\right)+\beta_{2}\left(\frac{\nabla R E V_{i, t}-\nabla R E C_{i, t}}{A_{i, t-1}}\right)+\beta_{3}\left(\frac{P E_{i, t}}{A_{i, t-1}}\right)+e_{i, t}$

where

$T A C C_{i, t}=$ total accruals of company $i$, in year $t$.

$A_{i, t-1}=$ total assets of company $i$, in year $t$.

$\triangle R E V_{i, t}=$ change in the revenues of company $i$, between the years $t$ and $t-1$.

$\triangle R E C_{i, t}=$ change in accountants under collection of company $i$, between the years $t$ and $t-1$.

$P P E_{i, t}=$ size of property, equipment and estate of company $i$, in year $t$.

$e_{i, t}=$ random error.

Third: Estimation of non-optional accruals using $\left(\beta_{1}, \beta_{2}, \beta_{3}\right)$ expected which were extracted from the previous equation is as follows:

$$
\mathrm{NACC}_{\mathrm{i}, \mathrm{t}}=\beta_{1}\left(\frac{1}{\mathrm{~A}_{\mathrm{i}, \mathrm{t}-1}}\right)+\beta_{2}\left(\nabla \mathrm{REV}_{\mathrm{i}, \mathrm{t}}-\nabla \mathrm{REC}_{\mathrm{i}, \mathrm{t}}\right)+\beta_{3}\left(\mathrm{PPE}_{\mathrm{i}, \mathrm{t}}\right)
$$

$N A C C_{i, t}=$ normal accruals of company $i$, in year $t$.

Fourth: After the estimation of total accruals and the non-optional accruals, the optional accruals are calculated by:

ANACC $_{i, t}=$ TACC $_{i, t}-N_{i, t}$

where:

$A N A C C_{i, t}=$ optional accruals of company $i$, in year $t$.

$N A C C_{i, t}=$ non-optional accruals of company $i$, in year $t$.

$T A C C_{i, t}=$ total accruals of company $i$, in year $t$.

Fifth: The value of the optional accruals is divided by the total assets, and then the absolute value is taken as follows:

Earnings management $=\left|\frac{A N A C C_{i}}{A_{i, t-1}}\right|$

The increase in the value of optional accruals indicates a decrease in earnings management through increased creative accounting practices by the company, and the decrease in the value of optional accruals indicates the increase in earnings management through reducing creative accounting practices by the company.

In order to classify the sample companies, where the decision rule is as follows: If the value of the optional accruals average for a company in all years exceeds the value of the optional accruals for the sample; this indicates its earnings management practices. While if the value of the optional accruals average for a company in all years decreases the value of the optional accruals for the sample; this indicates that there is no practice of earnings management (Dechow et al., 1995). 


\subsubsection{Income Smoothing}

The income smoothing measures the stability of the accounting earnings where it reduces the impact of future temporary fluctuations in earnings. It is measured by calculating the standard deviation ratio of net income divided by the total assets of the beginning of the period to the standard deviation of cash flows from operations divided by the total assets of the beginning of the period of the sample companies, according to the methodology used in the study (Francis et al., 2004) and according to the following equation:

$\mathrm{SMOOTH}_{\mathrm{j}}=\frac{\sigma\left(\mathrm{NI}_{\mathrm{j}, \mathrm{t}} / \mathrm{BTA}_{\mathrm{j}, \mathrm{t}}\right)}{\sigma\left(\mathrm{CFO}_{\mathrm{j}, \mathrm{t}} / \mathrm{BTA}_{\mathrm{j}, \mathrm{t}}\right)}$

where:

$\mathrm{SMOOTH}_{\mathrm{j}}$ : the income smoothing of a company,

$\sigma:$ standard deviation,

$\mathrm{NI}_{\mathrm{j}, \mathrm{t}}$ : net income of the year,

BTA $_{j, t}$ : total assets at the beginning of the year,

$\mathrm{CFO}_{\mathrm{j}, \mathrm{t}}$ : Net cash flows from operating activities.

The increase of SMOOTH value indicates the decrease in earnings management, through increasing creative accounting practices, and the decrease of SMOOTH value indicates the increase in earnings management, through decreasing creative accounting practices.

In order to classify the sample companies; the decision rule is as follows: If the average value of SMOOTH for a company in all years of study decreases the average value of SMOOTH for the sample; there is no practice of earnings management through income smoothing (Francis et al., 2004).

The financial performance which was measured by earnings per share is through the following equation (Matar, 2016):

Earnings Per Share $=\frac{\text { Net Income }- \text { Dividends for Preferred Stock }}{\text { Number of Common Shares }}$

1- The size of the audit office (Big4): This variable was measured by classifying the auditing companies into two groups, where the first group includes the Big 4 companies, while the second group includes the other auditing companies.

2- The company size ( Log (Size)): the company size was measured in this study by calculating the natural logarithm of total assets.

\subsection{Empirical Findings and Discussion}

The collected data were analyzed in order to obtain the results of the sample companies. This part contains three main sections. The first section includes the descriptive analysis of the study data to describe the study sample using the descriptive statistical measures. The second section includes verification of the study data and its validity for the statistical analysis and the Multicolinarity Test. The third section examined the hypotheses of this study were tested by using the Multiple Regression model and the Stepwise Multiple Regression.

\subsection{Descriptive Statistics}

After collecting the financial statements of the quantitative variables (earnings per share, and the company size measured by the asset size) from the financial reports of the sample companies, the descriptive analysis was conducted as follows:

Table 1

Results of the descriptive analysis of the earnings per share and company the size

\begin{tabular}{ccc}
\hline Measurements variables & EPS & Company size \\
\hline Number of observations & 360 & 360 \\
Minimum & -0.66 & 394795 \\
Maximum & 1.56 & 296459154 \\
Mean & 0.078 & 34406601 \\
Std. Deviation & 0.289 & 43174248 \\
\hline
\end{tabular}

It is noted that the arithmetic mean for the dependent variable which is earnings per share was $(0.078)$, where this value indicates the Jordanian industrial companies achieved earnings from their operations and benefited their shareholders. According to the lowest value of earnings per share which was (-0.66), which was associated with the National Steel Manufacturing Company in 2008, that there are companies suffered losses during the study years. The highest value of earnings per 
share in the sample companies which was (1.56), related to Al-Iqbal Investment Company in 2017. According to the control variable (company size measured by the asset size), it is noted that the arithmetic mean of the asset size of the company reached (34406601), where the high value of the size average of the assets can be explained by the nature of the work of the sample companies. The industrial companies depend on the assets (land, factories, equipment and machines) in the production processes. Also, referring to the highest value of the asset size reached (296459154) and the lowest value reached (394795), it is noted that there were large differences in the size of the sample companies, which explains the increase in value of the standard deviation which was (43174248).

After collecting the financial statements of the financial reports of the sample companies for the first independent variable which is earnings management method through depending on the modified Jones model (Dechow et al., 1995), the descriptive analysis of earnings management method was conducted as follows:

\section{Table 2}

Results of descriptive analysis of earnings management method

\begin{tabular}{ccccc}
\hline Year & Minimum & Maximum & Mean & Std. Deviation \\
\hline 2008 & 0.0037 & 1.7931 & 0.3039 & 0.3864 \\
2009 & 0.0026 & 1.4875 & 0.2961 & 0.3484 \\
2010 & 0.0010 & 1.3294 & 0.3013 & 0.3347 \\
2011 & 0.0021 & 1.1842 & 0.2955 & 0.3167 \\
2012 & 0.0027 & 1.3453 & 0.2746 & 0.3206 \\
2013 & 0.0014 & 1.4507 & 0.3082 & 0.3420 \\
2014 & 0.0125 & 1.3383 & 0.2925 & 0.3100 \\
2015 & 0.0074 & 1.2173 & 0.2807 & 0.2946 \\
2016 & 0.0051 & 1.2034 & 0.2814 & 0.2746 \\
\hline 2017 & 0.0205 & 1.1273 & 0.2946 & 0.3204 \\
\hline
\end{tabular}

*Number of companies practicing earnings management: 10

*Number of companies non-practicing earnings management: 26

It is noted from the table that the lowest level of earnings management which is measured by the optional accruals was in (2010) where the value of optional accruals was (0.0010), while the highest level of earnings management was in (2008), where the value of optional accruals was (1.7931). It is also noted that the average of the optional accruals for each of the years $(2012,2014,2015$, and 2016) did not exceed the average of the optional accruals for all years where it reached (0.2929), which indicates that there is no earnings management in these years compared with the general average, while the other years $(2008,2009,2010,2011,2013$ and 2017) were higher than the overall average, and the standard deviation for the years as a whole was (0.3204). According to the arithmetic mean of the optional accruals for all sample companies in all years which reached (0.2929), it was found that 26 companies did not exceed their average of optional accruals during the years of study for the arithmetic mean of the optional accruals of all the study sample companies such as the Industrial Agricultural Trading Company and the Jordanian Chemical Industries Company, while 10 companies exceeded their average of optional accruals during the study years for the same arithmetic mean such as the multi-project integrated company and the Arab company for the manufacture of pesticides and veterinary medicines. In another way, this means that $27.8 \%$ of sample companies practice earnings management over the years, and $72.2 \%$ of sample companies did not exercise earnings management over the years. After collecting the financial statements of the financial reports of the sample companies for the second independent variable which is income smoothing through depending on the Francis et al. (2004) model, the descriptive analysis of income smoothing was conducted as follows:

Table 3

The results of descriptive analysis of income smoothing

\begin{tabular}{cccc}
\hline Minimum & Maximum & Mean & Std. Deviation \\
\hline 0.1970 & 1.837 & 0.738450 & 0.36376 \\
\hline *Number of companies practicing income smoothing: 17 & &
\end{tabular}

*Number of companies non-practicing income smoothing: 19

According to Table 3, it is noted that the lowest level of income smoothing reached (0.197), which refers to the multi-project integrated company, while the highest level of income smoothing reached (1.837), which refers to Jordanian pharmaceutical company. It is also noted that the arithmetic mean of income smoothing of all the sample companies reached (0.738). By comparing the size of income smoothing of each of the sample companies with the previous arithmetic mean, it was found that 17 companies practiced creative accounting through income smoothing during the study period such as Jordanian Industrial Resources Company and Arabian Electrical Industries Company, while 19 companies did not practice creative accounting through income smoothing such as National Company for Chlorine Industry and Jordanian Pipes Manufacturing Company. In other ways, $47.2 \%$ of the study sample companies practiced income smoothing during the period of study, and $52.8 \%$ of the study sample companies did not practice income smoothing during the study years. Based on the results of descriptive analysis of creative accounting practices through earnings management methods and income smoothing, it was found that the 
practice of income smoothing was more common and used than earnings management method in public shareholding companies. According to the dummy variable represented by (big four), the necessary data were collected from the financial statements of the companies, and the value (1) was given to the auditing companies associated with an international company while and the value (2) was given to the auditing companies which are not associated with an international company. The results of the descriptive analysis are as follows:

Table 4

Results of descriptive analysis of the dummy variable of the study

\begin{tabular}{cccc}
\hline Variable & Classification & Frequency & Percentage \\
\hline \multirow{2}{*}{ Big4 } & Big4 audit firm & 240 & 66.7 \\
& Non-Big4 audit firm & 120 & 33.3 \\
\hline
\end{tabular}

Table 4 presents the results of the descriptive analysis of the control variable which is the size of the audit office. According to the above table, it is noted that most of the annual reports of the study sample are audited by companies that are not associated with international companies, where there were 240 annual reports audited by auditing companies and these reports are $66.7 \%$ of the annual reports of the study sample. Examples of these companies are professional observers Gamal Hammouda \& Co., the Auditing Standard and Ibrahim Yassin \& Co., while there was a small percentage reached 33.3\% of the annual reports of the sample companies were audited by companies associated with international companies and their numbers were 120 reports, for instance, Deloitte, Ernst and Young Jordan.

\subsection{Validation of data}

It is important to ensure that the study data met the conditions that confirm that it is suitable for the hypothesis analysis tests. In order to ensure that there was no problem in linear interference, variance inflation factor (VIF) and tolerance coefficient will be used, as shown in Table 5 as follows:

Table 5

The validity of the study data for statistical analysis

\begin{tabular}{cccc}
\hline \multirow{2}{*}{ Variables } & Variable's & \multicolumn{2}{c}{ Multicollinearity } \\
\cline { 3 - 4 } & & Tolerance & VIF \\
\hline \multirow{2}{*}{ Independent } & Earnings Management (EM) & 0.959 & 1.042 \\
& Income Smooth (IS) & 0.914 & 1.094 \\
\multirow{2}{*}{ Control } & Log(Size) & 0.986 & 1.014 \\
& Big4 & 0.879 & 1.138 \\
\hline
\end{tabular}

Variance inflation factor (VIF) is used to determine interference between variables and the general rule of VIF. There is inflation according to this indicator when the value is greater than 10, thus, the regression coefficients are poorly determined due to increased inflation between independent variables (Schreiber-Gregory and Jackson, 2017). According to Table 5, all values were less than 10 in relation to the inflation coefficient. As for tolerance coefficient, it is another test that used to detect the self-correlation problem. It can be determined that there is a problem of self-correlation if the tolerance factor value is less than (0.20). As for Table 5, all values were greater than (0.20) in relation to the inflation coefficient. Based on the hypotheses of the two previous indicators, it is clear that all study variables exceeded these two indicators, which means that there is no problem of linear interference and self-correlation in the study model.

\subsection{Empirical Results and Discussion}

Ho1: There is no statistically significant effect at $(\alpha \leq 0.05)$ for creative accounting methods practices on EPS in industrial companies listed on the ASE.

In order to determine the result of the main null hypothesis, the study used multiple regression analysis. The Sig F value was adopted to accept or reject the study model and to determine the extent of its suitability to represent the relationship between the independent variables and the dependent variable, where the decision rule indicates that the model is accepted when the Sig $F$ value is less than 0.05. In order to determine the impact of each one of the independent variable separately on the dependent variable, the Sig T value was adopted in this study, where the decision rule indicates that there is an effect when the value of Sig $\mathrm{T}$ is less than (0.05) in order to accept the alternative hypothesis and reject the null hypothesis, and in order to indicate the accuracy of the explanation of the independent variables to the dependent variable, the adjusted $\mathrm{R}$ Square value was adopted.

The next section presents the results of multiple regression analysis with an explanation of these results for the study model, and then the results will be compared with previous literature and studies.

The study model

$E P S=\beta_{0}+\beta_{1} \times E M+\beta_{2} \times I S+\beta_{3} \times \log ($ Size $)+\beta_{4} \times$ Big $_{4}+\varepsilon$ 
The study model was designed to examine the impact of creative accounting methods measured by: earnings management and income smoothing on earnings per share of Jordanian public shareholding industrial companies in light of the existence of both the company size under auditing and the size of the audit office as control variables. Table 6 below shows the results of the multiple regression test of the study model:

Table 6

Multiple regression test results for the study model

\begin{tabular}{cccccc}
\hline Variable & $\beta$ & Coefficient & Std. Error & T-Statistic & Prob. \\
\hline Constant & -1.034 & ------ & 0.221 & -4.689 & 0.000 \\
EM & -0.146 & -0.162 & 0.046 & -3.192 & 0.002 \\
IS & -0.107 & -0134 & 0.041 & -2.580 & 0.010 \\
Log(Size) & 0.170 & 0.285 & 0.030 & 5.717 & 0.000 \\
Big4 & -0.008 & -0.013 & 0.032 & -0.248 & 0.804 \\
\hline
\end{tabular}

$\begin{array}{lc}\text { R } & 0.357 \\ \text { R-squared } & 0.128 \\ \text { Adjusted R-square } & 0.118 \\ \text { S.E. of regression } & 0.2722 \\ \text { F-statistic } & 12.980 \\ \text { Prob(F-statistic) } & 0.000\end{array}$

It is noted from the table that the value of F calculated reached (12.980), at a significant level (0.05), indicating that the first proposed model of the study is suitable. The results of regression analysis show that the value of Sig F reached ( 0.000$)$, which is less than the significance of the test which is $(0.05)$. Therefore, the main null hypothesis should be rejected and the alternative hypothesis should be accepted, which means that there was a significant impact of creative accounting practices (earnings management and income smoothing) on earnings per share in public shareholding industrial companies listed in ASE. The results indicated that the adjusted $\mathrm{R}^{2}$ value reached $(0.118)$, which means that only about $11.8 \%$ of the fluctuations in the earnings per share of the industrial companies, can be explained by the changes that occur in creative accounting practices represented by (earnings management and income smoothing) in light of the existence of the first control variable which is the company size under auditing. The significant decrease in the adjusted $\mathrm{R}^{2}$ value indicates that there are other factors outside the interrelationship between these two variables may mutually affect each other.

In order to determine the impact of creative accounting practices on earnings per share industrial companies listed in ASE, the multiple regression test results were adopted as follows:

- Ho1-1: There is no statistically significant impact at the level $(\alpha \leq 0.05)$ of the practices of earnings management on earnings per share industrial companies listed in ASE.

It is noted from Table 6 that the value of Sig T which was less than (0.05) reached (0.002), and according to the decision rule that indicates to reject the null hypothesis and accept the alternative hypothesis if the Sig $\mathrm{T}$ is less than (5\%), and thus earnings management impact on earnings per share of companies. Accordingly, earnings management can be used to predict earnings per share for the public shareholding industrial companies which are the study sample. As for the coefficient value which reached (-0.162), there is a negative impact of earnings management on determining earnings per share, which indicates that earnings management is the most influential factor in determining EPS for companies among the practices of creative accounting methods in this study.

- Ho1-2: There is no statistically significant impact at the level $(\alpha \leq 0.05)$ of the practices of income smoothing on earnings per share industrial companies listed in ASE.

It is noted from Table 6 that the value of Sig T which was less than (0.05) reached (0.010), and according to the decision rule that indicates to reject the null hypothesis and accept the alternative hypothesis if the Sig T is less than (5\%), and thus income smoothing impacts on earnings per share of companies. Accordingly, income smoothing can be used to predict earnings per share for the public shareholding industrial companies which are the study sample. As for the coefficient value which reached $(-0.134)$, there is a negative impact of income smoothing on determining earnings per share, which indicates that income smoothing is the second influential factor in determining EPS for companies among the practices of creative accounting methods in this study.

Also, the results of the regression analysis indicate that some of the control variables impact on earnings per share of companies. It was also found that the company size under auditing and measured by the normal logarithm of total assets as the first control variable has a positive impact on earnings per share of companies, where the coefficient value reached $(\beta=0.285)$ at a significant level $(\operatorname{Prob}=0.000)$. Finally, the results of the analysis indicate that the second variable which is the size of the audit office had no impact on earnings per share of companies, where the coefficient value reached $(\beta=-0.013)$, which is not significant at the probability level $($ Prob $=0.804)$. 


\section{Conclusion}

This study was aimed at investigating the impact of creative accounting methods represented by (Earnings Management and Income Smoothing) on earnings per share in the Jordanian industrial companies. The model of Dechow et al. (1995) was adopted to measure earnings management, and the model of Francis et al. (2004) was adopted to measure income smoothing. In order to achieve the objectives of the study, the analytical quantitative approach was adopted. The study community consisted of the industrial companies listed on the Amman Stock Exchange which are 57 companies. As for the study sample, 36 companies were selected according to the target sample method in the period from 2008 to 2017.

The study revealed that there was a statistically significant impact of the practice of creative accounting methods, measured earnings management and income smoothing on earnings per share the preparation of income on the return on stock in the industrial companies listed on the Amman Stock Exchange. It was found the acceptance of the study model related to the ability of creative accounting practices adopted by the industrial companies' managements to predict earnings per share of these companies, and this model was characterized by convenience and explanatory power, but weakly, where the value of (Adjusted R Square $=0.118$ ).

The reason of this result is because EPS is one of the most important financial ratios taken into account by investors and stakeholders in making their financial and investment decisions, and the decrease in the arithmetic mean of EPS of the study sample where it reached (0.078) was an incentive for these companies managements to resort to the practice of creative accounting methods through earnings management and income smoothing in order to increase this percentage and change earnings to maintain investors and attract more of them. Also, the practice of creative accounting gives the company a bad reputation for decision makers due to the low reliability of its financial figures presented in its lists, which negatively affects the value of its shares and thus its financial performance. The results of the study showed that $27.8 \%$ of the industrial companies used earnings management and $47.2 \%$ of them used income smoothing.

The study recommended to emphasize the application of sanctions to all those who practice creative accounting methods in order to manipulate the earnings quality and mislead the financial statements, to develop more legislation focused reducing the practice of creative accounting practices, in addition to the existence of sanctions to deter the cases of manipulation and distortion in the financial statements, to conduct further studies and researches in this field, and to re-apply this study to other sectors of Jordanian companies in order to build on the results of the current study in an obvious image on the impact of creative accounting methods on EPS in all companies.

\section{References}

Acharya, V. V., \& Lambrecht, B. M. (2015). A theory of income smoothing when insiders know more than outsiders. The Review of Financial Studies, 28(9), 2534-2574.

Ba'aj, Q. M. (2018), the impact of creative accounting methods on the accounting information quality: a field study on a sample of financial reports of companies listed in the Iraqi Stock Exchange, unpublished PhD dissertation, University of Neelain, Khartoum, Republic of Sudan.

Bora, J., \& Saha, A. (2016). Investigation on the presence of income smoothing among nse-listed companies. IUP Journal of Accounting Research \& Audit Practices, 15(1), 55.

Dechow, P. M., Sloan, R. G., \& Sweeney, A. P. (1995). Detecting earnings management. Accounting Review, 70(2), $193-225$.

Francis, J., LaFond, R., Olsson, P. M., \& Schipper, K. (2004). Costs of equity and earnings attributes. The accounting review, 79(4), 967-1010.

Jabbar, N. S. (2015), creative accounting methods and its impact on the reliability of financial data: a field study in a sample of Iraqi Public Companies. Al Ghari Journal of Economic and Administrative Sciences, 32(10), 263-238.

Hamada, R. (2010). Role of audit committees in limiting creative accounting practices. Damascus University Journal of Economic and Legal Sciences, 26(2).

Hatef, M., Al-Saadi, A., \& Al Shawi, I. (2015). earnings management and its relation with earnings per share: applied study on a sample of industrial companies in the United Arab Emirates. Journal of Economic and Financial Research, 2(4).

Al-Hadi, A., Abdul-Hussein, M., \& Abdullah, K. (2017). The impact of creative accounting methods on accounting information quality: a field study on the financial reports of companies listed in the Iraqi Stock Exchange. Journal of the Faculty of Administrative Sciences, 1.

Khattab, M.S.Y. (2012). Proposed framework for activating the role of corporate governance in limiting the use of some creative accounting methods: a field study on Saudi companies, Journal of Public Management, 52(2).

Matar, M. (2016). Financial and credit analysis, the practical methods, tools and uses. $4^{\text {th }}$ ed., Wael Publishing House, Amman, Jordan.

Matar, M.N., \& Halabi, A. N. (2014). earnings management methods and its impact on the reliability of published financial statements of Jordanian Public Shareholding Companies, Erbid Journal of Research and Studies, 19(2).

Mostafa, W. (2017). The impact of earnings management on the value relevance of earnings: Empirical evidence from Egypt. Managerial Auditing Journal, 32(1), 50-74.

Naffaa, A.M. (2015). The impact of the Jordanian external auditor's commitment of the analytical procedures in reducing creative accounting practices: a field study, unpublished master thesis, Jerash University, Jordan.

Al-Khouri, A.F., \& Shakhatra, M.Z. (2014). The use of income smoothing practices in the Jordanian Services Sector. The Jordanian Journal of Business Management, 10(4), University of Jordan, Amman, Jordan. 
Al- Shammari, M.D. (2016). The impact of income smoothing on financial performance: applied study on Housing Bank for Trade and Finance, unpublished master thesis, Middle East University, Amman, Jordan.

Abdul Rahman, A., \& Hashim, O. M. (2016). The impact of earnings management practices on financial performance evaluation: applied study on banks listed in Khartoum Stock Exchange. Journal of Economic Sciences, 17(2), Neelain University, Khartoum, Republic of Sudan.

Al-Qari, M.B.M. (2010). Creative accounting motivations and methods in the shareholding companies in Saudi Arabia, unpublished master thesis. King Abdulaziz University, Saudi Arabia.

Rahman, M. M., Moniruzzaman, M., \& Sharif, M. J. (2013). Techniques, motives and controls of earnings management. International Journal of Information Technology and Business Management, 11(1), 22-34.

Schreiber-Gregory, D. N., \& Jackson, H. M. (2017). Multicollinearity: what is it, why should we care, and how can it be controlled.

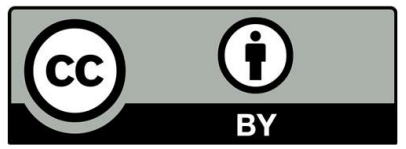

(C) 2020 by the authors; licensee Growing Science, Canada. This is an open access article distributed under the terms and conditions of the Creative Commons Attribution (CC-BY) license (http://creativecommons.org/licenses/by/4.0/). 